\title{
Approaches to Translation in the Context of Theory of Speech Activity
}

\section{Підходи до перекладу в контексті теорії мовленнєвої діяльності}

\author{
Serhii Zasiekin \\ Ph.D. in Linguistics, \\ Associate Professor
}

\author{
Сергій Засєкін \\ кандидат філологічних наук, \\ доцент
}

E-mail: s.zasyekin@gmail.com orcid.org/0000-0001-9453-3534

Scopus Author ID: 35112194200

Researcher ID: C-3094-2016

\author{
Lesya Ukrainka Eastern \\ European National University \\ $\triangle 13$, Voli Avenue, Lutsk, \\ Ukraine, 43025
}

Східноєвропейський начіональний університет імені Лесі Українки

$\triangle$ пр. Волі, 13, м. Луцьк, Україна, 43025

Original manuscript received March 14, 2018

Revised manuscript accepted October 14, 2018

\begin{abstract}
Over the past decades there has been a significant increase in the studies exploring cognitive foundations of translation reflected in a considerable amount of literature published on the topic. However, it is important to bear in mind that many of the ideas in the cognitive literature are mainly rooted in the psycholinguistic approaches to translation. For instance, a lot of scholarly works on translation in the former Soviet Union published in 1960-1970s emphasise the role of translator's thinking and speech processes. The emergence of 'theory of speech activity', Soviet version of Western psycholinguistics, stimulated interest of linguists and psychologists who considered translation and interpreting, their procedural aspects worthy of scholarly attention. A. Leontyev (1969), one of the founders of the above mentioned 'theory', paid special attention to translator's mental operations
\end{abstract}


and probabilistic programming of the target language utterance(s). Thus far, a number of recent cognitive translation studies have confirmed the effectiveness of previous psycholinguistic models of translation designed within the framework of theory of speech activity. The goal of the study is a theoretical review of psycholinguistic approaches to interpreting and translation discussed in the works of scholars who were part of the Soviet theory of speech activity. The main objective is to reveal the translator's status, his/her thinking and speech operations as psycholinguistic units in the approaches under review. Together, the psycholinguistic studies reviewed in the paper support the notion that the translator relies both on his/her algorithmic actions and heuristic solutions with the latter based on his/her background guided by probability thinking mechanism. This integrated approach proves useful in expanding our better and deeper understanding of translator's activity.

Key words: translation, psycholinguistics, theory of speech activity.

\section{Вступ}

Споконвіку дарована людині мова й здатність висловлювати нею думки є не лише засобом пізнання самого себе або іншого на теренах рідного краю, а й містком до осягнення вмісту колективної та індивідуальної свідомості носія іншої мови, народу, його письменників - представників, буває, зовсім незнайомої далекої землі із барвистою палітрою їі мови, багатими традиціями, розмаїтою культурною спадщиною й унікальною ментальністю. Незримим мірилом зв'язків між близькими й дистантними лінгвокультурними спільнотами, а також між літературною спадщиною народів світу постає переклад. Його роль сьогодні важко переоцінити, адже кожне чужоземне слово, наново творене на нашому грунті й виплекане багатьма поколіннями українських перекладачів, здобуває цінність через відкриття ще одного психоенергетичного каналу комунікації та психосеміотичного зближення між культурами. Відмінності в методах, стратегіях і підходах до перекладу, корені яких приховані в психічному устрої суб'єкта цієї діяльності, свідчать про те, що переклад можна трактувати з різних іпостасей - як науку, ремесло чи як мистецтво (Ваард \& Найда, 1998: 224). I кожен перекладач, лише спираючися на власний досвід, може судити про те, чим насправді є переклад.

Наукове обгрунтування перекладу, природно, взяло на себе перекладознавство, яке досить переконливо пояснює справедливість 
існування першого й другого елемента тріади. Так, панівний донині лінгвістичний підхід до перекладу, без сумніву, виявився надважливим етапом у становленні та бурхливому розвитку перекладознавчої думки останніх десятиліть. Завдяки йому відбувся відхід від теорій «неперекладності», поставлено на порядок денний i розв'язано низку важливих завдань щодо граматичних, лексико-семантичних трансформацій, лінгвальних особливостей i технік усного й письмового різножанрового перекладу, способів відтворення цільовою мовою власних імен, фразеологічних одиниць, слів-реалій тощо. Водночас, лінгвістичний підхід здебільшого грунтується на пошуку відмінностей структури мови оригіналу й мови перекладу, полягаючи у використанні певного набору правил відповідностей, залежних від поверхових, а не глибинних (семантичних) структур (Ваард \& Найда, 1998: 222-223). Тому мовознавча парадигма засвідчила, що перекладу певною мірою можна навчити, вдосконалити навички й автоматизувати вміння питання часу й зусиль, а отже, переклад $є$ ремеслом.

Утім лінгвістика перекладу не спромоглася цілковито розв'язати завдання доведення того, що переклад може бути мистецтвом, позаяк не залишила простору процесам розуміння (Hatzidaki, 2007), творчим механізмам мислення активного учасника процесу транскодування - перекладача, його евристичному началу (Ребрій O. \& Ребрій I., 2018). Тому перекладознавство нині розширює свої обрії, дедалі частіше звертаючися до здобутків інших наукових дисциплін. Окрім семіотики, психології, теорії комунікації й антропології, його увага звернена до психолінгвістики - порівняно молодої науки, поштовхом до появи якої в середині минулого століття почасти були проблеми перекладу: психолінгвістику на зорі свого існування тлумачили як науку про білінгвізм та переклад.

Психолінгвістичний підхід до перекладу набуває сьогодні антропоцентричного забарвлення, позаяк когнітивноінтелектуальним й емоційно-мотиваційним аспектам особистості перекладача, механізмам його мислення та мовленнєвих стратегій, визначенню його посередницького статусу в міжмовній i міжкультурній комунікації відведено тут центральну роль. Тому активне розроблення цього підходу в наших працях (Засєкін 2012; Zasiekin, 2010; 2016; 2018), видається плідним через наявність низки переваг: закладені в ньому принципи перекладу грунтуються 
на пошуку схожостей, а не відмінностей між в(и)хідною та цільовою мовами, установленні спільних перекладацьких стратегій, характерних для всіх або більшості перекладачів.

Актуальність психолінгвістичних студій процесу перекладу викликана пожвавленням інтересу науковців до процесів мислення та творчості перекладача, свідченням чому $є$ поява на зламі тисячоліть грунтовних робіт у галузі дескриптивного перекладознавства, в яких акцентується на перекладі як співтворчій діяльності автора й перекладача, визначенні психолінгвістичного статусу перекладача як посередника міжкультурної комунікації. Тому психолінгвістичний діяльнісний підхід до перекладу з урахуванням праць класиків i сучасників перекладознавства й прикладної психолінгвістики дає можливість накреслити модель процесу перекладу.

Водночас не слід забувати, що психолінгвістичні ідеї щодо усного й письмового перекладу на наших теренах започатковано в працях групи перекладознавців, які вийшли з лона радянської версії західної психолінгвістики - «теорії мовленнєвої діяльності» під проводом О.О. Леонтьєва. Серед них мовознавці В.М. Крупнов, А.Ф. Ширяев, Г.В. Чернов, О.Д. Швейцер (Крупнов, 1976; Ширяев 1979; Чернов 1984; Швейцер 1973) і психологи: В.О. Артемов, Б.В. Беляєв, .А. Бенедиктов (Артемов, 1969; Беляев, 1965; Бенедиктов, 1974) та ін.

\section{Методи дослідження}

Метою розвідки $є$ теоретичний огляд та аналіз психолінгвістичних концепцій усного та письмового перекладу в працях представників радянської теорії мовленнєвої діяльності. Головним завданням постало з’ясування статусу перекладача, місця мисленнєво-мовленнєвих операцій як психолінгвістичних одиниць у проаналізованих концепціях.

\section{Обговорення результатів}

Під час пошуку нових орієнтирів у перекладознавстві нині дедалі частіше дослідники звертають увагу на ідеї психолінгвістики (Hatzidaki, 2007), котру визначають як науку, що вивчає «устрій i функціонування мовленнєвих механізмів людини» (Леонтьев, 1976), «предметом якої $є$ відношення між системою мови <..> і мовною здатністю» (Леонтьев, 1969: 106), включаючи експериментальне 
дослідження психологічної діяльності суб'єкта із засвоєння та використання системи мови (КСКТ: 147). Це - галузь знань, що вивчає процеси розуміння, породження та запам'ятовування мовлення (Harley, 2008: 4). Оскільки об'єктом психолінгвістики є мовленнєва діяльність, а об'єктом теорії перекладу - особливий вид мовленнєвої діяльності - переклад, завдання цих дисциплін багато в чому суголосні.

У своїй праці «В творческой лаборатории переводчика» В.М. Крупнов наголошує на неможливості аналізу перекладу будь-яких текстів без урахування новітніх ліінгвістичних, психологічних та психолінгвістичних відкриттів. Російський дослідник покликається на українського перекладознавця В.В. Коптілова, який ставив на порядок денний питання «розумних» меж вільного перекладу почасти через ігнорування тодішніми літературознавцями основ теорії перекладу. Така практика вела перекладача до «мовного недбальства та неохайності стилю» (Цит. за: Крупнов, 1976). У такому підході до перекладу підтинається сутність мисленнєвих операцій перекладача, з'являється ризик буквалізму. Буквальний переклад «забуває» про загальнокомунікативні психолінгвістичні поняття, як-от: мовна норма, ідіоматичність мовлення (особливо усного), усталені впродовж історії розвитку будь-якої мови мовні традиції (Крупнов, 1976: 16). В.М. Крупнов утверджує й підкреслює творче начало в перекладі, вважаючи, що під час відтворення важких текстів набагато яскравіше, ніж у будь-якій іншій творчій діяльності, мисленнєвий процес усвідомлюється як процес, пов'язаний із постановкою та рішенням найрізноманітніших задач. Бувши здебільшого творчим пластичним процесом, переклад і мислення, спираються на готові стереотипи, на акумульований досвід. У цьому й полягає діалектика професійного перекладу, який В.М. Крупнов уважає радше не лінгвістичним, а «психолінгвістичним актом» (Крупнов, 1976: 175-176).

У праці «Синхронный перевод» А.Ф. Ширяєв заклав експериментальні психолінгвістичні підвалини усного перекладу. Працюючи також у річищі діяльнісного підходу радянської психолінгвістики - теорії мовленнєвої діяльності перекладознавець визначає нагальність погляду на переклад за термінами Л.С. Виготського, - аналізу за одиницями, а не за елементами, при цьому перші зберігають властивості цілого 
(перекладацької діяльності). Вивчення одержаних у цей спосіб одиниць дає змогу здійснити моделювання міжмовної діяльності перекладача. Наступним принципом перекладацької діяльності автор уважає положення про іiі тричленну будову. У відповідності до цього положення діяльність можна розглядати як таку, що складається 3: а) фази орієнтування в умовах завдання й вибору плану дій; б) фази здійснення та в) фази зіставлення результату 3 поставленою метою.

Третім принципом діяльності перекладача психолінгвіст визначає евристичність процесів сприйняття та породження висловлювань: під час відпрацювання способу дії та іï реалізації перекладач може варіювати стратегії залежно від конкретних умов діяльності. Нарешті, четвертий методологічний принцип полягає в конкретному розумінні процедури вибору способу дії, що може бути названим імовірнісним прогнозуванням (Ширяев, 1979: 12-13).

Ідея ймовірнісного прогнозування впродовж оцінки ситуації та вибору способу дії бере витоки з поняття «моделі майбутнього» М.О. Бернштейна. Сутність цієї моделі полягає у виникненні в суб'єкта образу ситуації, внаслідок відбиття якого його свідомість конструює модель «минулого-теперішнього», що існує до початку дії. Ця модель, якій властиві однозначність і категоричність, звужує разом із мотивацією можливості вибору способу дії. Водночас у свідомості суб'єкта формується уявлення про модель майбутнього, трансформовану через його втручання нову ситуацію, яка не має однозначного й категоричного характеру. Вона натомість має ймовірнісні риси, позаяк випрацювана на основі минулого досвіду, пов'язаного з діями в схожих випадках, а також шляхом спроб та «зондувань». Відтак із низки можливих результатів суб'єкт вибирає один шляхом зіставлення ймовірнісної моделі майбутнього й завдання дії (Бернштейн, 1966: 288).

Суб'єкт цілковито усвідомлює лише провідний рівень психофізіологічної побудови, що регулює ключові в смисловому аспекті компоненти його діяльності, керуючи нижчими рівнями, які покликані обслуговувати фонові чи технічні компоненти. На нижчих щаблях ступінь усвідомлення знижується за збільшення ступеня автоматизованості дій (Бернштейн, 1966: 99). Ще одним стрижневим моментом психолінгвістичної концепції А.Ф. Ширяєва є підтримка ним тези М.I. Жинкіна щодо послуговування суб'єкта 
кодом внутрішнього (предметно-образного) та експресивного (зовнішнього) лінійного розгорнутого мовлення (Жинкин, 1998: 160), що по-особливому взаємодіють під час перекладу.

Модель М.О. Бернштейна покладена також в основу психолінгвістичної концепції усного перекладу Г.В. Чернова, у якій автор на основі експериментальних досліджень обстоює гіпотезу щодо дії механізму ймовірнісного прогнозування на вербальному рівні сполучуваності слів. Так, упродовж слухового сприйняття оригіналу перекладач-синхроніст висуває передбачення відносно того чи того смислового або вербального завершення намірів мовця. Їхнє висування перекладач здійснює шляхом підсвідомої (автоматичної) суб'єктивної оцінки апріорних імовірностей подальшого розвитку конкретної вербальної ситуації (Чернов, 1984). Одержані дослідником емпіричні дані дали йому змогу зробити важливі висновки щодо чинності в перекладача механізму ймовірнісного прогнозування i на рівні прогнозу сполучуваності слів і на вищому смисловому рівні.

Водночас автор не заперечує застосування перекладачем й інших стратегій, адже «застосована модель семантикосмислового рівня ймовірнісного прогнозування не лише не заперечує можливої стратегії підстановки прямих лексичних i синтаксичних відповідників у синхронному перекладі без переходу на глибинний рівень в межах окремого речення, але, навпаки <..> засвідчує евристичний принцип вибору стратегії перекладачем» (Чернов, 1984: 136).

О.Д. Швейцер запропонував прагматично-орієнтовану модель перекладу, яка в більшій мірі стосується письмового перекладу, модель проб та помилок. Пошук оптимального рішення під час перекладу полягає, на думку автора, в послідовному наближенні до оптимального варіанта шляхом перебору декількох можливих версій і відхилення тих, що не відповідають конкретним функціональним критеріям (Швейцер, 1973: 60). Ця модель, поряд із іншими, не може претендувати на універсальність, однак вона узгоджується 3 описаною вище «моделлю майбутнього» в плані наявності вибору перекладачем того чи того способу дій на основі оцінки результатів наявної ситуації (Швейцер, 2012: 23).

Ще один аспект моделі О.Д. Швейцера торкається проблеми перекладацької компетентності, яку, як застерігає вчений, слід 
розуміти нарізно від потрактування мовної компетенції/здатності Н. Чомським. Перекладацька компетенція представляє складну й багатовимірну категорію, що охоплює весь спектр кваліфікаційних характеристик, які дають змогу перекладачеві здійснювати акт міжмовної й міжкультурної комунікації. Ідеться про особливе «перекладацьке» володіння двома мовами; здатність перекладача до емпатії з носієм цільової мови й культури; володіння технологією перекладу; знання норм мови перекладу, стилю й жанру тексту, а також перекладацьких норм, що визначають вибір стратегії перекладу; наявність мінімуму фонових знань перекладача, нарешті творчі здібності для перекладача художнього тексту i т. ін. Проблема компетентності перекладача, як стверджує автор, ще чекає на свою експериментальну розробку 3 позиції психолінгвістики (Швейцер, 2012: 28). Як зазначає О.Д. Швейцер, дані психолінгвістики щодо механізмів породження та сприйняття мовленнєвого висловлювання, структури мовленнєвої дії й моделей мовної здатності варто застосовувати до теорії перекладу (Швейцер, 2012: 21). Цю думку підтримує також Л.С. Бархударов, який виключає здатність якоїсь однієї універсальної моделі вичерпно пояснити процес перекладу, вважаючи його дослідження в аспекті психолінгвістики цікавим й актуальним завданням (Бархударов, 1975: 5).

Окремо слід згадати психологів, які поважно ставилися до вивчення проблем перекладу. Б.В. Беляєв уважав вивчення психологічних рис мислення рідною та іноземною мовами та питання реалізації цих рис під час перекладу головною проблематикою психології перекладу. Тому мовний переклад потрібно, на його думку, вважати не особливим видом мовленнєвої діяльності людини, а особливим мисленнєвим процесом, що лише грунтується на мовленнєвій діяльності, проте особливого виду мовлення не утворює (Беляев, 1965: 161).

В.О. Артемов стверджував, що психологічне вивчення всіх аспектів комунікації дає змогу розкрити психологічну сутність мовлення та мови, визначити правила спілкування на основі мови та інші закономірності, що реалізує перекладач під час своєї роботи (Артемов, 1969).

Б.А. Бенедиктов, проаналізувавши проблему замін між мовами і всередині однієї мови, дійшов висновку, що здійснення замін у 
перекладі триває не лише на основі нормативних відповідників, а й має відбиток досвіду самого перекладача (Бенедиктов, 1974). Отож, ця теза суголосна поглядам В.М. Крупнова, а також більшості перекладознавців - адептів теорії мовленнєвої діяльності.

Насамкінець зазначимо, що сам засновник теорії мовленнєвої діяльності О.О. Леонтьєв, вважав, що для всіх видів перекладу провідною рисою $є$ заданість програми зовні. Її реалізацію зумовлено попереднім досвідом індивіда, який дає змогу здійснювати ймовірнісне прогнозування, а іiі структуру зумовлюють чинники ситуації та контексту, що мають стосунок до перекладу і що потрібно залучати під час психологічного аналізу перекладу. (Леонтьев 1969а: 169).

Звісно, погляди на переклад відтоді еволюціонували, але ідея О.О. Леонтьєва щодо широкого й повного висвітлення різних аспектів перекладу із залученням даних багатьох наук (Леонтьев, 1969б) живе й донині. Отже для перекладознавців XXI століття переклад так само постає як мисленнєва, за нинішніми термінами «когнітивна», діяльність перекладача в соціокультурному контексті. Діяльнісний інтерпретативний підхід до розуміння процесу перекладу, як зазначає I.C. Шевченко, передбачає певною мірою реконструкцію перекладачем діяльності автора впродовж породження тексту оригіналу (Шевченко, 2003: 7). У контексті «когнітивної транслятології» перекладацьку діяльність потрактовують як реалізацію взаємодії когнітивних i мовних структур індивіда (перекладача) в найширшому контексті його психосеміотичної характерології. Перекладачеві відведено не другорядну роль вербального перекодувальника, а інтерпретатора смислового коду, закладеного у в(и)хідному тексті (Фесенко, 2002: 133).

Тому для когнітивного моделювання перекладацького процесу потрібно виходити не 3 настанови, яка грунтується на «міжмовних трансформаціях» (Гарбовский, 2007: 363). Натомість слід додержуватися погляду, що переклад - багатоплановий i багатовимірний вид людської діяльності, що закумулював у собі проблеми філософії, психології, лінгвістики, фізіології та інших галузей науки (Zlobin, 2003). Відтак, природно, що сьогоднішній погляд на переклад як на діяльність і засіб міжмовної 
комунікації цілковито узгоджується 3 положеннями радянської психолінгвістики, - «теорії мовленнєвої діяльності» (Засєкін, 2012).

\section{Висновки}

Узагальнюючи вже викладені провідні концепції перекладу, запропоновані представниками теорії мовленнєвої діяльності, підкреслимо, що психолінгвістичний вимір перекладу сприяє тлумаченню міжмовної комунікації як мовленнєво-мисленнєвої діяльності перекладача, із унікальною можливістю бодай частково «зазирнути» в його розум, проаналізувати мозкові процеси під час цієї діяльності. Ще одним важливим висновком $є$ той, що ментальні процеси, пов'язані 3 переробленням даних, можуть тривати в ментальності перекладача не лише алгоритмічно, - в строгій логічній послідовності, а й евристично, на основі висунутої півстоліття тому радянськими психолінгвістами ідеї ймовірнісного прогнозування.

Такий комплексний погляд на переклад як на багатобічну динамічну творчу сутність уможливлює емпіричний пошук i об’єктивне встановлення закономірностей цього інтелектуально складного, багато в чому загадкового та багатогранного виду людської діяльності.

\section{Література}

Артемов В.А. Конспект вводных лекций по курсу «Психология перевода».

Москва: МГПИИЯ имени М. Тореза, 1969.

Бархударов Л.С. Язык и перевод. Вопросы общей и частной теории перевода.

Москва : Междунар. отношения, 1975. 240 с.

Беляев Б.В. Очерки по психологии обучения иностранным языкам. Москва : Просвещение, 1965. С. 149-161.

Бенедиктов Б.А. Психология овладения иностранным языком. Минск: «Вышэйшая школа», 1974.

Бернштейн Н.А. Очерки по физиологии движений и физиологии активности. Москва : Медицина, 1966.

Ваард, Я. де, Найда Ю. На новых языках заговорят (Функциональная эквивалентность в библейских переводах) / ред. пер. с англ. А.А. Алексеев. СПб.: Рос. библ. общество, 1998. 271 с.

Выготский Л.С. Мышление и речь. Москва: Лабиринт, 2001. 368 с.

Гарбовский Н.К. Теория перевода. 2-е изд. Москва : Изд-во Моск. ун-та, 2007. 544 c.

Жинкин Н.И. Язык. Речь. Творчество: Исследования по семиотике, психолингвистике, поэтике. Москва : Лабиринт, 1998. 366 с. 
Засєкін С.В. Психолінгвістичні універсалії перекладу художнього тексту: Монографія. Луцьк: ВНУ ім. Лесі Українки, 2012. 275 с.

Засєкін С., Розенгарт Ю. Психолінгвістичні комп'ютерні інструменти лінгвістичного та перекладознавчого аналізу дискурсу. Psycholinguistics. Психолінгвістика. Психолингвистика. Вип. 23(2). С. 94-106. doi.org/10.5281/ zenodo.1204994

Крупнов В.Н. В творческой лаборатории переводчика. Москва : Междунар. отношения, 1976. 190 с.

КСКТ: Краткий словарь когнитивных терминов / под общ. ред. Е.С. Кубряковой. Москва : МГУ, 1996. 245 с.

Леонтьев А.А. (а). Психолингвистические единицы порождения речевого высказывания. Москва : Наука, 1969.

Леонтьев А.А. (б). Смысл как психологическое понятие. Психологические и психолингвистические проблемы владения и овладения языком. Москва : МГУ, 1969. С. 56-61.

Леонтьев А.А. Психолингвистический аспект языкового значения. Принцииь и методы семантических исследований. Москва, 1976. С. 46-73.

Ребрій О., Ребрій I. Системність і творчість у перекладі: психолінгвістичний підхід. Psycholinguistics. Психолінгвістика. Психолингвистика. Вип. 23(2). C. 180-191. doi.org/10.5281/zenodo.1199186

Фесенко Т.А. Специфика национального культурного пространства в зеркале перевода. Тамбов: ТГУ, 2002. 228 с.

Чернов Г.В. Психолингвистические основы синхронного перевода. Москва: МГПИИЯ, 1984. 79 с.

Швейцер А.Д. Перевод и лингвистика (Газетно-информационный и военнопублицистический перевод). Москва: Воениздат, 1973. 280 с.

Швейцер А.Д. Теория перевода: статус, проблемы, аспекты. Изд. 3-е. Москва : ЛИБРОКОМ, 2012. 216 с.

Шевченко И.С. Герменевтический аспект перевода как вторичной метакоммуникации. Вісник ХНУ ім. В.Н. Каразіна. 2003. Вип. 609. С. 7-11.

Ширяев А.Ф. Синхронный перевод. Деятельность синхронного переводчика и методика преподавания синхронного перевода. Москва: Воениздат, 1979. 183 с.

Harley, T. (2008). The Psychology of Language. From Data to Theory. N.Y.: Psychology Press.

Hatzidaki, A. (2007). The process of comprehension from a psycholinguistic approach implications for translation. Meta, 52(1), 13-21. doi.org/10.7202/014715ar

Zasiekin, S. (2010). Translation as a psycholinguistic phenomenon. Journal of Psycholinguistic Research, 39(3), 225-234. doi.org/10.1007/s10936-009-9134-2

Zasiekin, S. (2016) Understanding translation universals. Babel: International Journal of Translation, 62(1), 122-134. doi.org/10.1075/babel.62.1.07zas

Zlobin, A. (2002). Kognitive Modellierung der Übersetzung. TRANS. InternetZeitschrift für Kulturwissenschaften, 14. Retrieved from: http://www.inst.at/ trans/14Nr/zlobin14.htm

\section{References}

Artiomov, V. (1969). Konspekt Vvodnykh Lektsii po Kursu «Psikhologiya Pervoda» [Introductory Lectures on Psychology of Translation]. Moscow: Moscow State Pedagogical Institute of Foreign Languages [in Russian]. 
Barkhudarov, L. (1975). Yazyk i Perevod. Voprosy Obshchei $i$ Chastnoi Teorii Perevoda [Langauge and Translation. Issues of General and Private Theory of Translation]. Moscow: Mezdunarondyie Otnosheniya [in Russian].

Beliayev, B. (1965). Ocherki po Psikhologii Obucheniya Inostrannym Yazykam [Outlines on Psychology of Teaching Foreign Languages]. Moscow: Prosveshcheniye [in Russian].

Benediktov, B. (1974). Psikhologiya Ovladeniya Inostrannym Yazykom [Psychology of Foreign Language Acquisition]. Minsk: Vysheyshaya Shkola [in Russian].

Bernstein, N. (1966). Ocherki po Fiziologii Dvizheniy i Fiziologii Aktivnosti [Outlines on Physiology of Motion and Physiology of Activity]. Moscow: Meditsina [in Russian].

Chernov, G. (1984). Psikholinguisticheskiye Osnovy Sinkhronnogo Perevvoda [Psycholinguistic Bases of Simultaneous Interpreting]. Moscow: Moscow State Pedagogical Institute of Foreign Languages [in Russian].

Fesenko, T. (2002). Spetsifika Natsionalnogo Kulturnogo Prostranstva $v$ Zerkale Perevoda [National Cultural Space Specific in the Mirror of Translation]. Tambov: Tambov State University [in Russian].

Garbovsky, N. (2007). Teoriya Perevoda [Theory of Translation]. Moscow: Moscow University [in Russian].

Harley, T. (2008). The Psychology of Language. From Data to Theory. N.Y.: Psychology Press.

Hatzidaki, A. (2007). The process of comprehension from a psycholinguistic approach implications for translation. Meta. 52(1), 13-21. doi.org/10.7202/014715ar

Kratkiy Slovar Kognitivnykh Terminov [A Short Dictionary of Cognitive Terms]. (1996). Ye. Kubryakova, Ed. Moscow: Moscow State University [in Russian].

Krupnov, V. (1976). V Tvorcheskoi Laboratorii Perevodchika [In the Translator's Creative Laboratory]. Moscow: Mezhdunarodnyie Otnosheniya [in Russian].

Leontyev, A. (1969a). Psikholinguisticheskiye Yedinitsy Porozhdeniya Rechevogo Vyskazyvaniya [Psycholinguistic Units of Speech Untterance Production]. Moscow: Nauka [in Russian].

Leontyev, A. (1969b). Smysl kak Psikhologicheskoye Poniatiye [Sense as a Psychological Concept]. Psikhologicheskiye i Psikholinguisticheskiye Problemy Vladeniya i Ovladeniya Yazykom. (pp. 56-61). Moscow: Moscow State University [in Russian].

Leontyev, A. (1976). Psikholinguisticheskiy aspekt yazykovogo znacheniya [Psycholinguistic aspect of language meaning]. Principles and Methods of Semantic Studies. (pp. 46-73). Moscow [in Russian].

Rebrii, O., \& Rebrii, I. (2018). Systemic and creative aspects of translation: Psycholinguistic approach. Psiholingvistika - Psycholinguistics, 23(2), 180-191 [in Ukrainian]. doi.org/10.5281/zenodo.1199186

Shevchenko, I. (2003). Germenevticheskiy aspekt perevoda kak vtorichnoy metakommunikatsii [Hermeneutic aspect of translation as a secondary metacommunication]. Visnyk XNU im. V.N. Karazina - Visnyk of Vasyl Karazin National University of Kharkiv, 609, 7-11 [in Ukrainian].

Shveitser, A. (1973). Perevod i Linguistika [Translation and Linguistics]. Moscow: Voenizdat [in Russian].

Shveitser, A. (2012). Teoriya Perevoda [Theory of Translation] (3nd ed.). Moscow: Librokom [in Russian]. 
Shyriayev, A. (1979). Sinkhronnyi Perevod [Simultaneous Interpreting]. Moscow: Voenizdat [in Russian].

Vygotsky, L. (2001). Myshleniye i Rech [Thinking and Speech]. Moscow: Labirint [in Russian].

Vaard, Ya. de, \& Nayda Yu. (1998). Na novykh yazykakh zagovoryat (Funktsionalnaya ekvivalentnost $v$ bibleyskikh perevodakh) [From one Language to Another. Functional Equivalence in Bible Translating]. A. Alexeyev (Ed.). S.-Petrsburg: Russian Bible Society [in Russian].

Zasiekin, S. (2010). Translation as a psycholinguistic phenomenon. Journal of Psycholinguistic Research, 39(3), 225-234. doi.org/10.1007/s10936-009-9134-2

Zasiekin, S. (2012). Psykholinguistychni Universalii Perekladu Khudozhnioho Tekstu [Psycholinguistic Universals in the Translation of Literary Texts]. Lutsk: Lesya Ukrainka Volyn State University [in Ukrainian].

Zasiekin, S. (2016) Understanding translation universals. Babel: International Journal of Translation, 62(1), 122-134. doi.org/10.1075/babel.62.1.07zas

Zasiekin, S., \& Rosenhart, Yu. (2018). Psyxolingvistychni kompyuterni instrumenty lingvisty`chnogo ta perekladoznavchogo analizu dyskursu [Psycholinguistic Computerized Tools of Linguistic and Translation Studies Discourse Analysis]. Psyxolingvistyka - Psycholinguistics, 23(2), 94-106 [in Ukrainian]. doi. org/10.5281/zenodo.1204994

Zhinkin, N. (1998). Yazyk. Rech, Tvorchestvo: Issledovaniya po Semiotike, Psikholinguistike, Poetike [Language. Speech. Creativity: The Studies on Semiotics, Psycholinguistics, Poetics]. Moscow: Labirint [in Russian].

Zlobin, A. (2002). Kognitive Modellierung der Übersetzung. TRANS. InternetZeitschrift für Kulturwissenschaften, 14. Retrieved from: http://www.inst.at/ trans/14Nr/zlobin14.htm

\section{АНОТАЦІЯ}

Упродовж останніх десятиліть простежується суттєве пожвавлення в дослідженнях, які вивчають когнітивні основи перекладу, що відбито у великій кількості опублікованої літератури з проблеми. Водночас потрібно пам'ятати, що багато когнітивно орієнтованих ідей беруть свій початок від психолінгвістичних концепцій перекладу. Так, у значній кількості опублікованих у 1960-1970-х рр. праць, присвячених темі перекладу в тодішньому Радянському Союзі, автори відзначали важливу роль мисленнєво-мовленнєвих процесів перекладача. Із появою "теорії мовленнєвої діяльності», радянської версії західної психолінгвістики, лінгвістів та психологів тієї доби дедалі більше цікавили процедурні аспекти усного та письмового перекладу. Один із засновників згаданої «теорії» О. Леонтьєв звертав увагу дослідників до психічних операцій та ймовірнісних механізмів функціонування психіки перекладача під час породження речень/висловлювань цільовою мовою. Сьогодні багато авторів у галузі когнітивної транслятології засвідчують ефективність ранніх моделей перекладу, розроблених у межах «теорії 
мовленнєвої діяльності». Метою розвідки є теоретичний огляд та аналіз психолінгвістичних концепцій усного та письмового перекладу в працях представників радянської теорії мовленнєвої діяльності. Головним завданням постало з'ясування статусу перекладача, місия його мисленнєво-мовленнєвих операцій як психолінгвістичних одиниць у проаналізованих концепціях. Загалом, проаналізовані в цій оглядовій статті праці підтримують ідею про те, що перекладачі під час своєї діяльності вдаються $і$ до алгоритмічних дій $і$ до евристичних рішень, продиктованих їхнім досвідом, в основі якого лежить механізм імовірнісного прогнозування. Такий інтегрований підхід дає дослідникові змогу краще й глибше осягнути сутність перекладацької діяльності.

Ключові слова: переклад, психолінгвістика, теорія мовленнєвої діяльності.

\section{Засекин Сергей. Подходы к переводу в контексте теории речевой деятельности}

\section{АННОТАЦИЯ}

На протяжении последних десятилетий наблюдается существенное оживление в исследованиях, изучающих когнитивные основы перевода, что отражается в большом количестве опубликованной литературы по проблеме. В то же время, нужно помнить, что многие когнитивно ориентированные идеи исходят из психолингвистических концепций перевода. Так, в значительном количестве опубликованных в середине 1960-х г2. работ, посвященных теме перевода в тогдашнем Советском Союзе, авторы отмечали важную роль мыслительно-речевых процессов переводчика. С появлением "теории речевой деятельности», советской версии западной психолингвистики, лингвистов и психологов того времени все больще интересовали процедурные аспекты устного и письменного перевода. Один из основателей данной "теории» А. Леонтьев обращал внимание исследователей на психические операции и вероятностные механизмы функционирования психики переводчика при порождении высказывания в целевом языке. Сегодня многие авторы в области когнитивной транслятологии говорят об эфррективности ранних моделей перевода, разработанных в рамках «теории речевой деятельности». Целью разведки является теоретический обзор и анализ психолингвистических концепций устного и письменного перевода в трудах представителей советской теории речевой деятельности. Главной задачей явилось установление статуса переводчика, места его мыслительно-речевых операций как психолингвистических единиц в проанализированных 
Approaches to Translation in the Context of Theory of Speech Activity

концепциях. В целом, проанализированные в этой обзорной статье труды поддерживают идею о том, что переводчики во время своей деятельности пользуются как алгоритмическими действиями, так и эвристическиими решениями, продиктованными их опытом, в основе которого лежит механизм вероятностного прогнозирования. Такой интегрированный подход позволяет исследователю лучше и глубже понять сущность переводческой деятельности.

Ключевые слова: перевод, психолингвистика, теория речевой деятельности. 